Yoshef Arieka Marchel, Ratih Indraswari, dan Novia Handayani. Jurnal Promkes: The Indonesian Journal of Health Promotion and Health Education Vol. 7 No. 2 (2019) 144-155 doi: 10.20473/jpk.V7.12.2019.144-155

\title{
Implementasi Kawasan Tanpa Rokok Sebagai Pencegahan Merokok Pada Remaja Awal
}

\section{Implementation of Non-Smoking Area as Smoking Prevention in Early Adolescents}

\author{
Yoshef Arieka Marchel ${ }^{1)}$, Ratih Indraswari ${ }^{2)}$, Novia Handayani ${ }^{2)}$ \\ ${ }^{1}$ Dinas Kesehatan Kabupaten Madiun, Indonesia \\ 2 Departemen Promosi Kesehatan dan IImu Perilaku, Fakultas Kesehatan Masyarakat, Universitas \\ Diponegoro, Indonesia \\ Email: yoshefarie@gmail.com
}

\begin{abstract}
Background: Smoking behavior has been widespread in all community groups both globally and nationally, including adolescents. Middle school and equivalent is the main education for early teens, so it is necessary to create a non-smoking area in the school environment. Objective: The purpose of this study is to analyze the implementation of non-smoking areas in schools. Methods: The study used analytic descriptive and observational with cross-sectional approaches. Data were obtained using a structured questionnaire which was trialed at ten schools. The population of this study was 86 schools in Madiun Regency. Interviews were conducted with the person in charge of a smoking area in junior high school. The person responsible can be in the position of the principal, deputy, teacher, or public relations officer. Data were analyzed using univariate and bivariate analysis. Results: Bivariate analysis shows that there is a relationship between the implementation of a non-smoking area with the availability of financial resources with a p-value of 0.004 and the support of infrastructure with a $p$ value of 0.001 . While there is no relationship between the implementation of the nonsmoking area with the availability of human resources and policy support. Conclusion: The implementation of non-smoking areas in junior high schools and equivalent is not yet optimal, because there are still students, teachers and employees who behave in the school environment.
\end{abstract}

Keywords: school, early adolescent, non-smoking areas, cigarette

\begin{abstract}
ABSTRAK
Latar Belakang: Perilaku merokok sudah meluas pada seluruh kelompok masyarakat baik secara global maupun nasional, termasuk pada remaja. Sekolah Menengah Pertama (SMP) dan sederajat merupakan pendidikan utama untuk remaja awal, sehingga perlu mewujudkan kawasan tanpa rokok di lingkungan sekolah. Tujuan: Tujuan penelitian ini adalah menganalisis implementasi Kawasan Tanpa Rokok (KTR) di sekolah. Metode: Penelitian menggunakan deskriptif analitik dan observasi dengan pendekatan crosssectional. Data diperoleh dengan menggunakan kuesioner terstruktur yang telah diuji cobakan di sepuluh sekolah. Populasi penelitian ini sebanyak 86 sekolah di Kabupaten Madiun. Wawancara dilakukan pada penanggung jawab Kawasan Tanpa Rokok di SMP. Penanggung jawab tersebut bisa pada jabatan kepala sekolah, wakil, guru, atau humas. Data dianalisis secara univariat dan bivariat. Hasil: Analisis bivariat menunjukkan terdapat hubungan implementasi kawasan tanpa rokok dengan ketersediaan sumber dana dengan $p$-value 0,004 dan dukungan sarana prasarana dengan p-value 0,001. Sedangkan tidak ada hubungan antara implementasi Kawasan Tanpa Rokok dengan ketersediaan sumber daya manusia dan dukungan kebijakan. Kesimpulan: Implementasi Kawasan Tanpa Rokok di SMP dan sederajat masih belum maksimal, karena masih terdapat siswa, guru, dan karyawan yang berperilaku merokok di lingkungan sekolah.
\end{abstract}

Kata kunci : sekolah, remaja awal, KTR, rokok 


\section{PENDAHULUAN}

Perilaku merokok sudah meluas pada seluruh kelompok masyarakat baik di dunia dan di Indonesia, termasuk pada remaja. Indonesia adalah negara terbesar ketiga dalam konsumsi rokok. Dari survei Global Youth Tobacco Survey (GYTS) (2014), remaja mulai merokok terjadi pada jenis kelamin laki-laki dengan kelompok usia 12-13 tahun sebesar 43,4\%, pada kelompok umur 10 11 tahun sebesar 26,7\% (WHO, 2015). Sirkesnas 2016 menyebutkan, prevalensi usia merokok antara 10-18 tahun mencapai 8,8\% (Kementerian Kesehatan, 2016a), namun pada tahun 2018, prevalensi usia merokok di Indonesia pada kelompok usia 10-18 tahun meningkat $\quad 0,3 \%$ menjadi $9,1 \%$ (Kementerian Kesehatan RI, 2010).

Prevalensi merokok pada penduduk usia lebih dari sepuluh tahun di Provinsi Jawa Timur mencapai 23,9\% (Badan Pusat Statistik Provinsi Jawa Timur, 2016). Jumlah perokok ditahun 2018 terbanyak adalah perokok remaja mencapai 18,3\% (Kementerian Kesehatan RI, 2010). Banyaknya jumlah perokok remaja ini disebabkan oleh karena gencarnya promosi rokok di media dan cerdasnya produsen rokok dalam mempromosikan produk kepada targetnya yaitu remaja.

Masa remaja adalah sebuah masa yang konstruksi dan perkembangan yang dinamis disertai tanda perkembangan fisiologis, psikososial, temporal dan budaya. Setiap periode perkembangan remaja selalu diawali dengan proses pubertas serta pencarian jati diri baik pribadi, sosial dan masyarakat (DrPH Clea McNeely, 2015). Usia 10-15 tahun merupakan masa remaja awal (Sawyer et al., 2018), dimana remaja mudah terpengaruh oleh lingkungan sekolah. Lingkungan tersebut meliputi teman sebaya, keluarga yang merokok, pengaruh media iklan rokok di sepanjang jalan yang dilalui dari rumah ke sekolah, dan iklan rokok di media lain, karena remaja awal masih mengalami proses perkembangan fisik dan psikis dalam pencarian jatidiri (Mary Campbell, 2002; Willian T.O 'Donohue, Lorraine T.Benuto, 2013; Kementerian Kesehatan, 2011).

Sekolah merupakan sarana untuk mengikuti proses pendidikan formal supaya menambah pengetahuan dan keterampilan yang akan dijadikan bekal masa depan peserta didik (Kementerian Kesehatan, 2016b). Sekolah Menengah Pertama (SMP) mempunyai populasi yang terbesar kedua setelah Sekolah Dasar (Sd) yaitu 25\% (Kementerian Pendidikan dan Kebudayaan, 2018) dari seluruh jumlah peserta didik di Indonesia. Jumlah penduduk berusia 10-14 tahun telah mencapai lebih dari 22 juta jiwa (Badan Pusat Statistik Kabupaten Madiun, 2017). Presentase jumlah peserta didik SMP di Jawa Timur mencapai 30\%, sedangkan di Kabupaten Madiun mencapai 26\% (Kementerian Pendidikan dan Kebudayaan, 2018).

Pendidikan kesehatan lebih efektif bila dilakukan dengan sasaran siswa SMP. Lingkungan sekolah yang baik merupakan lingkungan yang melindungi civitas sekolah dari kecelakaan, dan penyakit, termasuk lingkungan yang bebas asap rokok (Kementerian Pendidikan dan Kebudayaan, 2012). Lingkungan sekolah harus menjadi kawasan tanpa asap rokok sesuai dengan Peraturan Kementerian Pendidikan dan Kebudayaan Nomor 64 tahun 2015.

Kawasan Tanpa Rokok (KTR) adalah cara untuk mengurangi polusi asap tembakau yang merugikan kesehatan. Asap tembakau bisa menyebabkan kanker paru-paru, penyakit jantung, asma pada anak-anak, dan kematian bayi mendadak (Fong et al., 2006). KTR di sekolah merupakan kegiatan promosi kesehatan pada remaja di lingkungan sekolah. Faktor-faktor risiko menjadi perokok dapat terhindarkan melalui pembinaan lingkungan sekolah yang bebas rokok (Trinidad, Gilpin and Pierce, 2005; Urbán, 2010).

Pelaksanaan implementasi Kawasan Tanpa Rokok (KTR) di sekolah belum optimal dijalankan secara baik dan hanya 57,2\% kabupaten/kota yang memiliki peraturan tentang KTR. Presentase sekolah yang telah menerapkan KTR dalam wilayah pemerintah kota secara nasional hanya 24,1\% dan 48,3\% tidak menerapkan KTR. Di wilayah pemerintah kabupaten di Indonesia yang telah menerapkan KTR sebesar $13,9 \%$ dan $53,3 \%$ belum menerapkan KTR di sekolah (Kementerian Kesehatan, 2016). Kabupaten Madiun mempunyai 48 Sekolah Menengah Pertama (SMP) Negeri dan Swasta, 38 Madrasah Tsanawiyah (MTs) Negeri dan Swasta. 
Sebanyak 96\% dari 86 SMP dan sederajat di Kabupaten Madiun, memiliki tata tertib tentang bebas rokok (Dinas Pendidikan dan Kebudayaan Kabupaten Madiun, 2017).

Pelaksanaan tata tertib mengenai KTR masih belum maksimal, karena masih didapatkan perilaku merokok guru, perilaku merokok pada remaja awal, iklan media rokok yang tersebar di luar sekolah dan orang tua yang merokok. Kabupaten Madiun merupakan salah satu kabupaten yang belum mempunyai Peraturan Daerah atau Peraturan Bupati tentang kawasan tanpa rokok dan lingkungan bebas asap rokok (Dinas Pendidikan dan Kebudayaan Kabupaten Madiun, 2017). Lingkungan tanpa rokok di sekolah sangat perlu dilakukan karena hal ini merupakan salah satu cara untuk mengurangi polusi asap tembakau, mengurangi dampak negatid pada perokok pasif, mengurangi prevalensi perokok remaja, dan menjadi sarana pengendalian tembakau (Borders et al., 2005). Penelitian ini dilakukan untuk menganalisis implementasi kawasan tanpa rokok di SMP untuk pencegahan merokok pada remaja awal di Kabupaten Madiun.

\section{METODE}

Penelitian ini menggunakan teori pendekatan sistem. Sistem merupakan elemen-elemen atau bagian yang terbentuk saling berhubungan dan mempengaruhi (Munijaya A, 2004). Elemen merupakan suatu yang harus ditemukan. Elemen-elamen tersebut meliputi masukan (input), proses, keluaran (output), umpan balik (feedback), dampak, dan lingkungan (environment) (Anwar, 2010). Penelitian ini menganalisis tentang proses implementasi, maka faktor yang diteliti merupakan bagian dari masukan suatu sistem. Masukan menjadi elemen penting dalam proses implementasi. Teori sistem menjelaskan yang paling mendasar pada proses implementasi adalah masukan. Masukan yang baik akan mempengaruhi implementasi yang baik pula (Arbib, 2000). Masukan suatu sistem meliputi ketersediaan sumber daya manusia (man), ketersediaan sumber dana(money), dukungan sarana prasarana (material), dan dukungan kebijakan (method) (Priliantining Asri Wulanningrum, Emmy Riyanti, 2016). Empat unsur masukan tersebut saling mempengaruhi berjalannya sebuah implementasi, apabila menghilangkan salah satu maka implementasi tidak berjalan maksimal. Metode yang digunakan dalam penelitian ini adalah observasional dengan pendekatan Cross-sectional secara kuantitatif (Kothari, 2004). Populasi dalam penelitian ini adalah SMP di Kabupaten Madiun. Sampel penelitian ini sebanyak 86 sekolah dengan teknik pengambilan sampel menggunakan total sampling technique. Kriteria inklusi dari penelitian ini adalah sekolah yang telah mengimplementasikan kawasan tanpa rokok (Notoadmojo, 2010; Bruce, Pope and Stanistreet, 2008). Penelitian ini dilaksanakan pada Maret-April 2019. Pengumpulan data dengan wawancara kepada penanggungjawab kawasan tanpa rokok di SMP dan dilakukan pengamatan lingkungan sekolah. Informan dalam penelitian ini adalah kepala sekolah, wakil kepala sekolah, humas, atau guru UKS. Dalam menentukan responden dengan memperhatikan hal berikut:

1. Responden yang tahu tentang keadaaan lingkungan kawasan tanpa rokok di sekolah menengah pertama dan sederajat.

2. Responden yang telah lama berkarya dalam sekolah menengah pertama dan sederajat.

3. Responden yang mengerti keadaaan dan ketersediaan sumber daya manusia

4. Responden yang mengerti keadaan dan ketersediaan sumber dana.

5. Responden yang mengerti keadaan dan dukungan sarana prasarana.

6. Responden yang mengerti keadaan dan dukungan kebijakan

Instrumen yang digunakan telah dilakukan uji coba pada sepuluh SMP di Kabupaten Ngawi. Variabel bebas adalah ketersediaan sumber daya manusia, ketersediaan sumber dana, dukungan sarana prasarana dan dukungan kebijakan sedangkan variabel terikatnya implementasi KTR. Penentuan kategori pada masing-masing variabel menggunakan nilai median, karena sebaran data yang didapat berdistribusi tidak normal. Hasil pengolahan data serta analisisnya menggunakan analisis univariat dan bivariate. Analisis bivariat menggunakan uji Chi-Square (Notoadmojo, 2010).

Hasil analisis fata disajikan dalam bentuk tabel dan narasi. Penelitian telah 
mendapat sertifikat etik dari Komite Etik Penelitian Kesehatan Fakultas Kesehatan Masyarakat Universitas Diponegoro Semarang dengan nomor sertifikat $151 /$ EA/KEPK-FKM/2019.

\section{HASIL DAN PEMBAHASAN}

Karakteristik jabatan responden yang diwawancara adalah kepala sekolah $(14 \%)$, wakil kepala sekolah $(31,4 \%)$, guru UKS $(10,5 \%)$, kepala tata usaha $(16,3 \%)$, humas $(3,5 \%)$ dan guru $(21,4 \%)$. Implementasi kawasan tanpa rokok Pada Sekolah Menengah Pertama dan Sederajat telah dinyatakan dengan baik. Hal ini sesuai dengan tabel 1.

Tabel 1. Distribusi Frekuensi Kategori Implementasi Kawasan tanpa Rokok

\begin{tabular}{lcc}
\hline \multicolumn{2}{c}{$\begin{array}{c}\text { Implementasi } \\
\text { KTR }\end{array}$} & \multicolumn{2}{c}{ Jumlah } \\
\cline { 2 - 3 } & Frekuensi & $\%$ \\
\hline Baik & 46 & 53,5 \\
Kurang Baik & 40 & 46,5 \\
\hline \multicolumn{1}{c}{ Total } & 86 & 100 \\
\hline
\end{tabular}

Responden memberikan jawaban 'baik' karena implementasi kebijakan KTR sesuai kebijakan Kementerian Pendidikan dan Kebudayaan. Sekolah mempunyai perencanaan kegiatan yang mendukung kawasan tanpa rokok, perencanaan pemasangan tanda larangan merokok, sekolah mempunyai penanggung jawab dan pengaturan tugas dalam implementasi. Sekolah telah melakukan sosialisasi, pembinaan, dan pemantauan implementasi KTR.

Implementasi KTR pada SMP dan sederajat kurang baik karena ada pihak yang tidak melakukan pemantauan kawasan tanpa rokok yaitu peserta didik dan petugas khusus. Ada pula pihak yang tidak melakukan pembinaan KTR yaitu komite sekolah, kepala sekolah, guru, dan staf dari Dinas Pendidikan dan Kebudayaan. Responden juga menyatakan bahwa masih terdapat penolakan saat pemasangan tanda larangan merokok di sekolah. Kondisi seperti ini yang bisa menghambat implementasi kawasan tanpa rokok di lingkungan SMP dan sederajat. Adanya hambatan ini kemudian diberikan solusi melalui pemberian sanksi bagi pelanggar. Sanksi tersebut telah dijelaskan pada saat sosialisasi implementasi kawasan tanpa rokok. Sanksi yang diberikan telah dijelaskan dengan baik saat peserta didik memulai masa belajar di SMP dan sederajat saat masa orientasi siswa, dan selalu diingatkan setiap upacara di hari senin. Sanksi untuk peserta didik jelas berupa teguran lisan dan teguran tertulis.

Hasil penelitian sebelumnya menunjukkan bahwa seluruh sekolah telah melaksanakan kawasan tanpa rokok melalui tata tertib sekolah, namun pengelola sekolah masih membiarkan adanya aktifitas merokok dan tidak ada pemasangan iklan rokok dilingkungan sekolah. Penelitian lain menyatakan bahwa pemerintah Kota Semarang telah menerbitkan kebijakan kawasan tanpa rokok namun implementasi kawasan tanpa rokok di beberapa STIKES di Kota Semarang masih kurang baik (Azizah, 2016; Setianingsih, Wahyati and Widyorini, 2015).

Penelitian ini dilakukan melalui pengamatan terhadap implementasi KTR pada 86 sekolah. Adapun hasil pengamatan dalam Tabel 2:

Tabel 2. Hasil pengamatan implementasi kawasan tanpa rokok

\begin{tabular}{lcccc}
\hline \multicolumn{1}{c}{ Pengamatan } & \multicolumn{2}{c}{ Ya } & \multicolumn{2}{c}{ Tidak } \\
\cline { 2 - 5 } & Frekuensi & $\%$ & Frekuensi & $\%$ \\
\hline Terdapat tata tertib yang terpasang & 71 & 82,6 & 15 & 17,4 \\
Terdapat pedoman implementasi KTR & 13 & 15,1 & 73 & 84,9 \\
Terdapat jadwal edukasi pembinaan KTR & 9 & 10,5 & 77 & 89,5 \\
Terdapat tanda larangan merokok & 61 & 70,9 & 25 & 29,1 \\
Tidak terdapat asbak & 76 & 88,4 & 10 & 11,6 \\
Tidak terdapat bilik rokok & 84 & 97,7 & 2 & 2,3 \\
Terdapat aktifitas merokok dalam sekolah & 10 & 11,6 & 76 & 88,4 \\
Terdapat iklan/promosi rokok di sekolah & 0 & 0 & 86 & 100 \\
Terdapat iklan/promosi rokok di luar sekolah & 6 & 7,0 & 80 & 90,0 \\
\hline
\end{tabular}

Tabel 2 menunjukkan bahwa sekolah telah memasang tata tertib sekolah dan memasang tanda larangan merokok. Pemasangan ini sebagai wujud bukti nyata dalam implementasi KTR. SMP juga tidak menyediakan sarana untuk 
merokok seperti asbak serta bilik merokok. Kondisi ini telah sesuai dengan Peraturan Kementerian Pendidikan dan Kebudayaan nomor 64 tahun 2015 menjelaskan bahwa sekolah tidak mempunyai bilik rokok, wadah abu rokok dan tidak diperkenankan ada penjualan serta promosi rokok di dalam atau diluar sekolah, hanya saja, masih ada ditemukan aktifitas merokok di dalam sekolah dan terdapat iklan/promosi rokok di luar sekolah. Sekolah belum memiliki pedoman implementasi KTR, hukuman yang tegas dan konsisten bagi yang melanggar serta tidak ada jadwal edukasi pembinaan kawasan tanpa rokok. Ketiga hal ini yang menjadi penyebab implementasi kawasan tanpa rokok di sekolah tidak berjalan baik dan optimal. Ketersediaan sumber daya manusia dinyatakan tersedia dalam implementasi KTR pada SMP dan sederajat.

Tabel 3. Distribusi frekuensi Kategori Ketersediaan Sumber Daya Manusia

\begin{tabular}{ccc}
\hline Ketersediaan & \multicolumn{2}{c}{ Jumlah } \\
\cline { 2 - 3 } $\begin{array}{c}\text { Sumber Daya } \\
\text { Manusia }\end{array}$ & Frekuensi & $\%$ \\
\hline Tersedia & 48 & 55,8 \\
Tidak tersedia & 38 & 44,2 \\
\hline Total & 86 & 100 \\
\hline
\end{tabular}

Tabel 3 menunjukkan bahwa setiap warga sekolah memiliki kewajiban untuk mendukung implementasi kawasan tanpa rokok sesuai yang diamanatkan dalam Peraturan Kementerian Pendidikan nomor 64 tahun 2015, karena sumber daya manusia cukup essensial dalam keberhasilan implementasi dan penegakan kebijakan. Sumber daya manusia disini maksudnya adalah sumber daya dilihat dari segi kuantitas dan kualitas dalam mengimplementasikan kawasan tanpa rokok (Ehan, 2015). Ketidak tersediaan sumber daya manusia disebabkan lintas sektor seperti masyarakat sekitar sekolah, puskesmas, dan orang tua yang tidak mendukung implementasi kawasan tanpa rokok di lingkungan sekolah. Hasil pengamatan menunjukkan bahwa masih dijumpai guru dan karyawan yang merokok di lingkungan sekolah, sehingga membuat remaja awal bisa mengikutinya. Responden penelitian yang mengatakan mendukung KTR di sekolah adalah seluruh warga sekolah yaitu kepala sekolah, guru, karyawan, peserta didik, komite sekolah dan orang tua serta stakeholder pendukung seperti puskesmas dan dinas pendidikan. Peran dukungan diberikan dari guru dan peserta didik baik di dalam atau luar ruangan (So et al., 2019). Bentuk-bentuk dukungan dalam mengimplementasikan KTR berbeda-beda sesuai dengan tugas dan fungsi masingmasing. Kepala sekolah sebagai pimpinan tertinggi di sekolah menjadi teladan bagi warga sekolah seperti berperilaku tidak merokok di sekolah, berperilaku tidak menjual rokok, dan memberikan sosialisasi, pembinaan, dan pengawasan.

$$
\text { Penelitian kualitatif yang }
$$

dilakukan Thurthon menyebutkan bahwa peranan orang dewasa dalam berperilaku tidak merokok dapat meningkatkan kepercayaan diri pada remaja untuk mengikuti program pencegahan merokok (Thurston et al., 2019). Dukungan stakeholder pada sekolah dalam hal ini adalah dinas pendidikan yaitu berupa pendanaan dan anggaran sosialisasi peraturan, serta monitoring KTR, sedangkan yang diberikan puskesmas mayoritas sebagai narasumber dalam penyelenggaraan sosialisasi. Kerjasama dalam lintas sektor dalam penanganan KTR di sekolah penting, karena dengan adanya komitmen dan kerjasama lintas sektor menjadikan pelaksanaan menjadi lebih baik (Rahajeng, 2015).

Waktu pemberian dukungan pembinaan dilakukan setiap kegiatan orientasi sekolah dan kegiatan belajar mengajar. Bentuk pembinaan dilakukan dalam bentuk penyuluhan. Sasaran penyuluhan yang terbesar adalah kepada peserta didik. Pemberian pengetahuan akan rokok, bahaya rokok, dan KTR di lingkungan sekolah yang dilakukan secara terus-menerus dan berkelanjutan akan meningkatkan pengetahuan. Tujuan dari penyuluhan ini adalah untuk meningkatkan pengetahuan peserta didik dan seluruh warga sekolah yang efektif (Widiastini, 2010). Pengetahuan yang baik akan sangat efektif dan signifikan dalam mengubah sikap dan praktek peserta didik tentang bahaya rokok dari kurang baik menjadi baik. Cindi (2017) diungkapkan bahwa terdapat hubungan antara pengetahuan dengan tindakan remaja awal terhadap kebijakan KTR di SMP Kristen Tateli ( $p$ value 0,019)(Cindy E. Z. Hutapea, Rumayar and Maramis, 2017; Maharani et al., 2018). 
Ketersediaan sumber daya manusia dalam penelitian ini bukan satusatunya variabel yang tidak berhubungan dengan implementasi. Kondisi ini disebabkan karena sumber daya manusia menjadi sasaran sebuah kebijakan dan sudah semestinya sumber daya manusia mendukung terhadap KTR di sekolah.

Tabel 6 menunjukkan bahwa implementasi KTR baik lebih banyak dijumpai pada kelompok yang tidak tersedia sumber daya manusia $(57,9 \%)$. Uji hubungan ketersediaan sumber daya manusia dengan implementasi KTR menunjukkanm, tidak terdapat hubungan yang signifikan.

$$
\text { Hasil penelitin ini sejalan dengan }
$$
penelitian sebelumnya bahwa ketersediaan sumber daya manusia dan penggerakan sumber daya manusia menjadi peranan yang terpenting dalam sebuah implementasi. Setiap implementasi kebijakan, sumber daya manusia menjadi sasaran implementasi itu sendiri. Analisis terhadap variabel sumber daya manusia menunjukkan hasil yang tidak signifikan terhadap proses implementasi ( $p$ value $>0,05) \quad$ (Santi, MArgawati and Mawarni, 2015); (M, 2013)(Lestari, 2017).

Ketersediaan sumber dana dengan implementasi KTR pada sekolah menengah pertama dan sederajat adalah tersedianya dana yang cukup. Ketersediaan dana yang cukup mempunyai peranan penting dalam penerapan KTR untuk pelaksanaan sosialisasi dan pemasangan tanda larangan merokok (Nizwardi Azkha, 2013). Sumber dana tidak hanya berasal dari pemerintah, namun berasal dari orang tua bahkan dari peserta didik, sebagai wujud pemberdayaan (Scheirer and Dearing, 2011) dan kepedulian orang tua terhadap lingkungan sekolah bebas rokok.

Tabel 4. Distribusi frekuensi Kategori Ketersediaan Sumber Dana

\begin{tabular}{ccc}
\hline Ketersediaan & \multicolumn{2}{c}{ Jumlah } \\
\cline { 2 - 3 } Sumber Dana & Frekuensi & $\%$ \\
\hline Tersedia cukup & 71 & 82,6 \\
Tersedia kurang & 15 & 17,4 \\
\hline Total & 86 & 100 \\
\hline
\end{tabular}

Hasil wawancara menunjukkan, sebagian besar responden mengatakan bahwa dana digunakan untuk kegiatan sosialisasi, pembuatan tanda larangan merokok, pemasangan tanda larangan merokok, dan dana pemeliharaan tanda larangan merokok. Responden yang menyatakan sumber dana yang tersedia kurang, karena tidak ada sumber dana yang mendukung seperti dari pemerintah (dana Bantuan Operasional Sekolah). Anggaran dari pemerintah (BOS) untuk mencakup 13 komponen kegiatan dan pengembangan belajar mengajar pada pendidikan dasar di SMP dan sederajat (Nizwardi Azkha, 2013; Silele et al., 2017). Ketiadaan sumber dana untuk KTR di sekolah disebabkan karena tidak tersedia anggaran untuk KTR. Implementasi kebijakan harus didukung dengan adanya anggaran yang memadai untuk terlaksananya penerapan KTR, sebab tanpa anggaran yang cukup, maka implementasi kebijakan tidak berjalan efektif.

Hasil uji bivariat pada Tabel 6 implementasi KTR yang kurang baik lebih banyak dijumpai pada kelompok yang ketersediaan dana kurang $(80,0 \%)$. Uji hubungan menunjukkan bahwa ada hubungan antara ketersediaan sumber dana dengan implementasi KTR pada sekolah menengah pertama dan sederajat di Kabupaten Madiun.

Hasil ini sejalan dengan hasil penelitian mix method yang mengatakan implementasi harus didukung dengan ketersediaan dana yang cukup, maka implementasi KTR di Kota Padang berjalan baik (Nizwardi Azkha, 2013). Faktor yang memengaruhi implementasi KTR di Surabaya adalah ketersediaan sumber dana yang cukup (Hartanto, 2015). Penelitian lain mengungkapkan ketersediaan sumber dana sangat berpengaruh dalam implementasi KTR di Universitas Andalas (Maharrani, Isniati and Astiena, 2015).

Ketersediaan sumber dana dalam penelitian ini tidak berhubungan karena ketersediaan sumber dana dalam implementasi KTR selalu diusahakan dengan pemberdayaan seluruh warga sekolah. Warga sekolah yang dimaksud mulai dari pemegang kebijakan yaitu kepala sekolah sampai peserta didik. Dukungan sarana prasarana dengan implementasi KTR pada sekolah menengah pertama dan sederajat menunjukkan sebagian besar responden mempunyai dukungan sarana prasarana yang mendukung implementasi KTR.

Sarana prasarana yang mendukung berpengaruh terhadap implementasi KTR di sekolah. Dukungan sarana prasarana 
tersebut meliputi keputusan kepala sekolah, pemasangan tata tertib, tanda larangan merokok dengan penggunaan komunikasi media yang efektif, lokasi pemasangan yang efektif dan tersebar dalam lingkungan sekolah memungkinkan adanya perubahan perilaku, sikap dan keyakinan bagi warga sekolah (Nizwardi Azkha, 2013)(Azmi, Istiati and Cahyo, 2016). Penelitian yang dilakukan oleh Nurnaningsih mengatakan dengan adanya pemasangan tata tertib dan tanda larangan merokok menimbulkan rasa tidak nyaman pada perokok (41,0\%) (Ulfah, Katmawanti and Tama, 2015).

Tabel 5 Distribusi Frekuensi Kategori Dukungan Sarana Prasarana dan Dukungan Kebijakan.

\begin{tabular}{|c|c|c|}
\hline \multirow{2}{*}{ Keterangan } & \multicolumn{2}{|c|}{ Jumlah } \\
\hline & Frekuensi & $\%$ \\
\hline \multicolumn{3}{|c|}{ Kategori dukungan sarana prasarana } \\
\hline Mendukung & 47 & 54,7 \\
\hline Kurang mendukung & 39 & 45,3 \\
\hline Total & 86 & 100 \\
\hline \multicolumn{3}{|c|}{ Kategori dukungan kebijakan } \\
\hline Mendukung & 52 & 60,5 \\
\hline Tidak Mendukung & 34 & 39,5 \\
\hline Total & 86 & 100 \\
\hline
\end{tabular}

Responden mengatakan dukungan diberikan dalam bentuk pemasangan tanda larangan merokok. Pemasangan tanda larangan merokok tersebut di ruang kelas, ruang guru, dan ruangan lain yang ada di sekolah. Tanda larangan merokok masih belum banyak terpasang di gerbang terluar sekolah.

Penelitian kualitatif sebelumnya menyatakan bahwa beberapa responden yang diwawancara mengatakan tempelan larangan merokok hanya di dalam gedung, tidak ditempel dalam lobi gedung dan tempelan poster kurang menarik (Waliyanti and Sandika, 2017). Rata-rata media sosialisasi yang digunakan adalah poster dan banner. Wulanningtum dan Riyanti (2016) mengatakan, media promosi kesehatan dalam penyampaian pesan kesehatan di sekolah yang paling banyak digunakan adalah media poster, banner dan stiker (Wulanningrum, dan Riyanti, 2016). Pemenuhan fasilitas dan sarana prasarana perlu dilakukan untuk mengimplementasi KTR secara efektif, misalnya dengan cara pemasangan media promosi kesehatan seperti spanduk, poster, dan stiker (Nizwandi Azkha, 2013). Pihak yang membuat tanda larangan merokok adalah pengadaan dari sekolah
(02019. Jurnal Promkes:

dan mayoritas yang memasang tanda larangan merokok adalah karyawan pada sekolah tersebut.

Lingkungan sekolah merupakan salah satu lingkungan sosial para remaja awal dalam mengenal perilaku-perilaku yang tidak baik termasuk budaya merokok. Sutha (2016) menjelaskan ada pengaruh yang signifikan antara perilaku merokok orang tua, guru, dan teman sebaya terhadap perilaku merokok pada remaja, sehingga diperlukan komitmen guru, karyawan, dan peserta didik yang membuat dan memasang tanda larangan merokok di sekolah agar remaja awal tidak terpapar perilaku merokok di lingkungan sekolah (Sutha, 2016).

Hasil analisa bivariat pada Tabel 6 menunjukkan bahwa implementasi KTR yang kurang baik lebih banyak dijumpai pada kelompok dukungan sarana prasarana yang kurang mendukung $(66,7$ $\%$ ). Uji hubungan implementasi KTR menunjukkan hubungan yang signifikan.

Hasil ini sejalan dengan hasil penelitian Kartini yang mengatakan dukungan sarana prasarana memiliki kriteria cukup dengan nilai persentase tertinggi yaitu lebih dari 80\% (Kartini, 2014). Dukungan sarana prasarana menjadi faktor penting dalam implementasi pelayanan kesehatan. Penelitian lain juga mengatakan bahwa dukungan sarana prasarana berpengaruh signifikan terhadap implementasi pembelajaran siswa. Pengaruh dukungan sarana prasarana ini sebesar 53\% (Jannah and Sontani, 2018).

Dukungan sarana prasarana dalam penelitian ini menjadi penting dan berhubungan pada implementasi KTR di SMP dan sederajat karena mengingat akan karakteristik sasaran yaitu remaja awal. Karakteristik remaja awal yakni yang masih dapat berkembang secara fisik, emosional, kognitif dan moral. Perilaku merokok remaja banyak meniru perilaku orang dewasa dan media iklan, oleh karena itu, diharapkan dukungan sarana prasarana termasuk peraturan dan media promosi kesehatan tentang bahaya rokok lebih digiatkan untuk mengurangi perilaku merokok pada remaja awal. Remaja awal akan menjadi model bagi teman sebayanya bahkan mengingatkan bagi keluarga atau orangtuanya.

Tabel 5 menampilkan dukungan kebijakan implementasi KTR pada SMP dan sederajat lebih banyak mendukung 
daripada yang tidak mendukung. Penelitian kualitatif yang dilakukan Ehan (2015) mengatakan kebijakan yang mendukung merupakan persyaratan yang utama dalam mengimplementasikan sebuah keputusan. Keputusan kebijakan yang tepat dan mendukung implementasi harus bisa diterima sasaran dengan jelas (Ehan, 2015). Penelitian yang lain menyebutkan, dukungan kebijakan yang mendukung implementasi KTR dapat menurunkan angka proporsi perilaku merokok (Rahajeng, 2015). Pada kategori yang tidak mendukung sesuai penelitian Nurnaningsih mengatakan dengan adanya kebijakan pelaksanaan KTR dan tanda larangan merokok menimbulkan rasa tidak nyaman pada perokok (Ulfah, Katmawanti and 2015).

Tabel 6. Variabel-variabel Bebas yang Diteliti dan Diuji Chi Square dalam Implementasi KTR pada SMP dan Sederajat

\begin{tabular}{|c|c|c|c|c|c|c|c|c|}
\hline \multirow{3}{*}{$\begin{array}{c}\text { Variabel } \\
\text { Bebas }\end{array}$} & \multicolumn{4}{|c|}{ Implementasi } & \multirow{2}{*}{\multicolumn{2}{|c|}{ Total }} & \multirow{3}{*}{$P$ value } & \multirow{3}{*}{ a } \\
\hline & \multicolumn{2}{|c|}{ Baik } & \multicolumn{2}{|c|}{ Kurang Baik } & & & & \\
\hline & Frekuensi & $\%$ & Frekuensi & $\%$ & Frekuensi & $\%$ & & \\
\hline \multicolumn{9}{|c|}{ Variabel yang berhubungan dengan implementasi KTR } \\
\hline \multicolumn{9}{|c|}{ Ketersediaan sumber dana } \\
\hline - Cukup & 43 & 60,6 & 28 & 39,4 & 71 & 100 & \multirow{2}{*}{0,004} & \multirow[b]{2}{*}{0,05} \\
\hline - Kurang & 3 & 20,0 & 12 & 80,0 & 15 & 100 & & \\
\hline \multicolumn{9}{|c|}{ Dukungan sarana prasarana } \\
\hline \multirow{2}{*}{$\begin{array}{l}\text { - Mendukung } \\
\text { - Kurang } \\
\text { mendukung }\end{array}$} & 33 & 70,2 & 14 & 29,8 & 47 & 100 & \multirow[b]{2}{*}{0,001} & \multirow[b]{2}{*}{0,05} \\
\hline & 13 & 33,3 & 26 & 66,7 & 39 & 100 & & \\
\hline \multicolumn{9}{|c|}{ Variabel yang tidak berhubungan dengan implementasi KTR } \\
\hline \multicolumn{9}{|c|}{ Ketersediaan Sumber Daya Manusia } \\
\hline - Tersedia & 24 & 50,0 & 24 & 50,0 & 48 & 100 & \multirow[b]{2}{*}{0,466} & \multirow[b]{2}{*}{0,05} \\
\hline $\begin{array}{l}\text { - Tidak } \\
\text { tersedia }\end{array}$ & 22 & 57,9 & 16 & 42,1 & 38 & 100 & & \\
\hline \multicolumn{9}{|c|}{ Dukungan Kebijakan } \\
\hline \multirow{2}{*}{$\begin{array}{c}\text { - Mendukung } \\
\text { - Tidak } \\
\text { mendukung }\end{array}$} & 27 & 51,9 & 25 & 48,1 & 52 & 100 & \multirow[b]{2}{*}{0,719} & \multirow[b]{2}{*}{0,05} \\
\hline & 19 & 55,9 & 15 & 44,1 & 34 & 100 & & \\
\hline
\end{tabular}

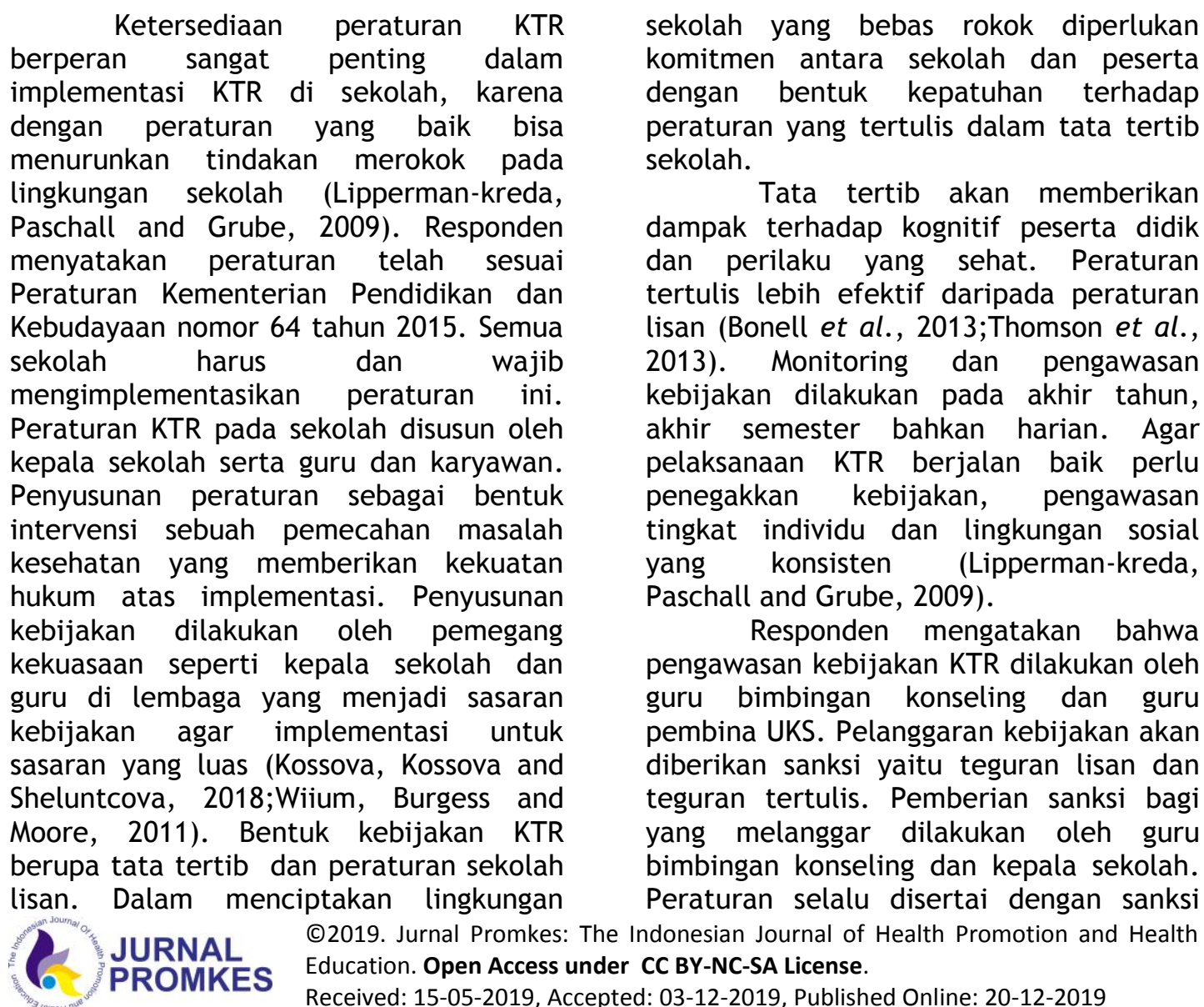

Ketersediaan peraturan KTR implementasi KTR di sekolah, karena dengan peraturan yang baik bisa menurunkan tindakan merokok pada lingkungan sekolah (Lipperman-kreda Paschall and Grube, 2009). Responde menyatakan peraturan telah sesuai sekolah harus dan wajib mengimplementasikan peraturan ini. Penyusunan peraturan sebagai bentuk intervensi sebuah pemecahan masala kesehatan yang memberikan kekuatan kebijakan dilakukan oleh pemegang kekuasaan seperti kepala sekolah dan Sheluntcova, 2018; Wiium, Burgess and Moore, 2011). Bentuk kebijakan KTR lisan. Dalam menciptakan lingkungan

sekolah yang bebas rokok diperlukan peraturan yang tertulis dalam tata tertib sekolah. dampak terhadap kognitif peserta didik dan perilaku yang sehat. Peraturan isan (Bonell et al., 2013; Thomson et al., 2013). Monitoring dan pengawasan . pelaksanaan KTR berjalan baik perlu penegakkan kebijakan, pengawasan individu dan lingkungan sosial yang konsisten (Lipperman-kreda, and Grube, 2009)

Responden mengatak guru bimbingan konseling dan guru pembina UKS. Pelanggaran kebijakan akan diberikan sanksi yaitu teguran lisan dan eguran tertulis. Pemberian sanksi bagi yang melanggar dilakukan oleh guru bimbingan konseling dan kepala sekolah. Peraturan selalu disertai dengan sanksi Received: 15-05-2019, Accepted: 03-12-2019, Published Online: 20-12-2019 
berupa teguran, sindiran, pengambilan kartu siswa, pengambilan rokok pelanggar bahkan sampai penghadapan ke guru bimbingan konseling. Evaluasi penerapan kebijakan KTR yang efektif selain dengan media promosi kesehatan juga dengan penerapan sanksi denda (Waliyanti and Sandika, 2017; Issel, Bayha and Nelson, 2018).

Tabel 6 menunjukkan bahwa uji hubungan antara dukungan kebijakan dengan implementasi KTR dinyatakan tidak berhubungan. Hasil ini sesuai dengan penelitian Francis di California mengatakan dukungan kebijakan tidak berpengaruh terhadap implementasi KTR tanpa didukung norma, budaya, dan perilaku masyarakat yang telah berlangsung lama (Francis, Abramsohn and Park, 2010). Nizwadi menyebutkan dukungan kebijakan tidak berpengaruh signifikan terhadap implementasi KTR di Kota Padang dan Kota Payakumbuh dengan $p$-value 0,102 yang berarti dukungan kebijakan tidak berpengaruh terhadap implementasi serta belum tegasnya sanksi untuk yang melanggar (Nizwandi, 2013). Penelitian Poweli menyatakan dukungan kebijakan tidak memengaruhi implementasi KTR pada remaja, tetapi dipengaruhi oleh faktor teman sebaya dan keterjangkauan harga rokok (Poweli, 2015).

Variabel dukungan kebijakan yang dianalisis dalam penelitian ini tidak berhubungan signifikan pada implementasi KTR pada sekolah menengah pertama dan sederajat. Dukungan kebijakan yang baik dan ketat adalah dukungan kebijakan yang dilakukan dengan komitmen para sasaran, dukungan kebijakan yang mempunyai sanksi bagi para pelanggar dan sanksi ini dijalankan dengan penuh komitmen oleh sasaran. Sanksi bagi peserta didik berupa teguran tertulis dengan pencatatan skor, sedangkan bagi guru yang melanggar diberikan peneguran lisan oleh kepala sekolah. Keberadaan sistem sanksi ini membuat remaja awal menjadi konsekuen terhadap peraturan atau kebijakan, karena secara karakteristik remaja awal menunjukkan perkembangan secara moral yaitu mulai menaati peraturanperaturan yang ada di lingkungan sekolah dan menjadi lebih konsisten akan hidupnya. Berkembang secara emosional karena kemampuannya meniru orang dewasa dalam patuh dan taat terhadap kebijakan yang ada.

\section{SIMPULAN}

Implementasi KTR di SMP dan sederajat masih belum maksimal, karena masih terdapat siswa, guru dan karyawan yang merokok di lingkungan sekolah. Kebijakan pelaksanaan KTR telah tersedia dan lengkap dengan punishment tetapi komitmen dalam implementasi dan punishment yang diberikan belum dilaksanakan secara tegas. Kondisi ini terjadi pada siswa, guru dan karyawan yang melanggar kebijakan KTR di lingkungan sekolah.

\section{DAFTAR PUSTAKA}

Anwar, A. (2010) Pengantar Administrasi Kesehatan. 3rd edn. Jakarta: Sinarupa Aksara.

Arbib, M. A. (2000) 'Précis of Neural organization: Structure , function , and dynamics', pp. 513-571.

Azizah, N. (2016) 'Faktor yang berhubungan dengan perilaku merokok di lingkungan sekolah', Ilmu Kesehatan Masyarakat, I.

Azkha, N. (2013) 'Studi Efektifitas Penerapan Kebijakan Perda Kota Padang Tentang Kawasan Tanpa Rokok dalam Upaya Menurunkan Perokok Aktif Di Sumatera Barat TAhun 2013', Jurnal kebijakan Kesehatan Indonesia, 04 Desembe(Volume 02), pp. 171179.

Azkha, N. (2013) 'Studi Efektiivitas Penerapan Kebijakan Perda Kota Tentang Kawasan Tanpa Rokok (KTR) Dalam Rangka Menurunkan Perokok Aktif DI Sumatera Barat Tahun 2013', Jurnal Kebijakan Kesehatan Indonesia, 02(04), pp. 171-179.

Azmi, F. Z., Istiati, T. and Cahyo, K. (2016) 'Hubungan Penerapan Kawasan Tanpa Rokok dengan Perilaku Merokok Mahasiswa Kesehatan Masyarakat di Kota Semarang', Jurnal Kesehatan Masyarakat, I.

Badan Pusat Statistik Kabupaten Madiun (2017) Kabupaten Madiun Dalam Angka 2016.

Badan Pusat Statistik Provinsi Jawa Timur (2016) Statistik Remaja Jawa

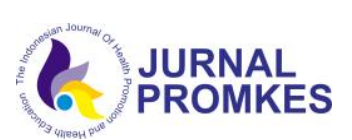

(C)2019. Jurnal Promkes: The Indonesian Journal of Health Promotion and Health Education. Open Access under CC BY-NC-SA License.

Received: 15-05-2019, Accepted: 03-12-2019, Published Online: 20-12-2019 
Timur 2015.

Bonell, C. P. et al. (2013) 'Health \& Place Theories of how the school environment impacts on student health: Systematic review and synthesis', Health \& Place. Elsevier, 24, pp. 242-249.

Borders, T. F. et al. (2005) 'College campus smoking policies and programs and students' smoking behaviors', 6, pp. 1-6.

Bruce, N., Pope, D. and Stanistreet, D. (2008) Quantitative Methods for Health Research: A Practical Interactive Guide to Epidemiology and Statistics. West Sussex, England: John Wiley \& Sons, Ltd.

Cindy E. Z. Hutapea, Rumayar, A. A. and Maramis*, F. R. R. (2017) 'Hubungan Antara Pengetahuan dan Sikap terhadap Kebijakan Kawasan Tanpa Rokok Pada Siswa Di SMP Kristen Tateli', Kesehatan Masyarakat Sam Ratulangi, II(I), pp. 1-13.

Dinas Pendidikan dan Kebudayaan Kabupaten Madiun (2017) 'Laporan Pengembangan SMP'.

DrPH Clea McNeely, M. (2015) 'The Teen Years Explained:A Guide Healthy Adolescent Development'. Bloomberg: John Hopkins, pp. 787.

Ehan, Z. (2015) 'Implementasi Kebijakan Pemerintah Tentang Penetapan Kawasan Tanpa Rokok Studi pada Rumah Sakit Umum Daerah Undata Propinsi Sulawesi Utara', e-Jurnal Katalogis, 3 nomor 5, pp. 58-67.

Fong, G. T. et al. (2006) 'Reductions in tobacco smoke pollution and increases in support for smokefree public places following the implementation of comprehensive smoke-free workplace legislation in the Republic of Ireland: findings from the ITC Ireland/UK Survey', Health Education Research, 20 No 4, pp. 51-58.

Francis, J. A., Abramsohn, E. M. and Park, H. (2010) 'Policy-driven tobacco control', 19(Suppl 1), pp. 16-20.

Hartanto, D. (2015) 'Implementasi Kebijakan Perda No 5 Tahun 2008 Kota Surabaya', Jurnal Kebijakan Dan Manajemen Publik, 3(5).

Issel, L. M., Bayha, K. and Nelson, A. (2018) 'Implementation phase of the Tobacco-Free Parks Ordinance: a policy evaluation using photographic data', Public Health. Elsevier Ltd, 167, pp. 1-7.

Jannah, S. N. and Sontani, U. T. (2018) 'Sarana dan prasarana pembelajaran sebagai faktor determinan terhadap motivasi belajar siswa ( Learning facilities and infrastructure as a factor determinant to student learning motivation )', 1(2), pp. 210-217.

Kartini, W. (2014) 'Pengaruh Pelaksanaan Kebijakan tentang Puskesmas dan Dukungan Sarana Prasarana terhadap Kawasan Tanpa Rokok Di Instansi Kesehatan', pp. 146-156.

Kementerian Kesehatan (2011) Pedoman Pengembangan Kawasan Tanpa Rokok. 1st edn. Jakarta: Pusat Promosi Kesehatan Kemenkkes RI.

Kementerian Kesehatan (2016a) Laporan Survei Indikator Kesehatan Nasional 2016.

Kementerian Kesehatan (2016b) Pedoman Akselerasi Pembinaan dan Pelaksana UKS. Jakarta.

Kementerian Kesehatan RI (2010) Riset Kesehatan Dasar. Jakarta.

Kementerian Pendidikan dan Kebudayaan (202AD) 'Pedoman Pembinaan dan Pengembangan Usaha Kesehatan Sekolah', 1.

Kementerian Pendidikan dan Kebudayaan (2018) Laporan Data Peserta Didik.

Kossova, T., Kossova, E. and Sheluntcova, M. (2018) 'Anti-smoking policy in Russia: Relevant factors and program planning', Evaluation and Program Planning. Elsevier, 69(March 2017), pp. 43-52.

Kothari, C. R. (2004) Research Methodology: Methods And Techniques. 2nd Revise. Jaipur, India: New Age International (P) Limited.

Lestari, P. (2017) 'Pengelolaan Sumberdaya manusia, sarpras dan dana ( studi kasus di SMA Negeri 1 Puokulon Tahun 2016-2017)', Ilmu Sosial.

Lipperman-kreda, S., Paschall, M. J. and Grube, J. W. (2009) 'Perceived enforcement of school tobacco policy and adolescents' cigarette smoking', Preventive Medicine. Elsevier Inc., 48(6), pp. 562-566.

M, W. (2013) 'Green Human resources 
benefits: do they matter as determinants of environmental management system implemetation', Journal of Business Ethics, 114 ( 3), pp. 443456.

Maharani, C. et al. (2018) 'Pengaruh Promosi Kesehatan Terhadap Pengetahuan dan Sikap Merokok Pada Pelajar Laki - Laki Di SMK Negeri 2 Kota Bitung', Kesmas, 7(5).

Maharrani, E., Isniati and Astiena, A. Ka. (2015) 'Studi implementasi kebijakan larangan merokok di universitas andalas tahun 2012', Jurnal Kes, pp. 3-9.

Mary Campbell (2002) 'A Reference For Professionals Developing Adolescent', American psychological association, 1 st, pp. 7-33.

Munijaya A, G. A. (2004) Manajemen Kesehatan. 2nd edn. Jakarta: Penerbit Buku Kedokteran EGC.

Notoadmojo, S. (2010) Metodologi Penelitian Kesehatan. Jakarta: RIneka Cipta.

Poweli, L. M. (2015) 'The importance of peer effects, cigarette prices and tobbacco policies for youth smoking behaviour', Journal of Health Economics, 24, pp. 950968.

Priliantining Asri Wulanningrum, Emmy Riyanti, K. C. (2016) 'Evaluasi Penerapan Kebijakan Peraturan Daerah Kota Semarang Nomor 3 Tahun 2013 Tentang Kawasan Tanpa Rokok Pada Program Studi Kesehatan Masyarakat Di Perguruan Tinggi Kota Semarang', Jurnal Kesehatan Masyarakat, 5(Volume 4, Nomor 5, Oktober 2016), pp. 362-369.

Rahajeng, E. (2015) 'Pengaruh Penerapan Kawasan Tanpa Rokok Terhadap Penurunan Proporsi Perokok Di Provinsi DKI Jakarta, Daerah Istimewa Yogjakarta, dan Bali', Pusat Teknologi Intervensi Kesehatan Masyarakat.

Santi, M. Y., MArgawati, A. and Mawarni, A. (2015) 'Faktor komunikasi dan ketersediaain sumber dana manusia dalam implementasi konseling air susu ini oleh bidan konselor ASI', Kebidanan Politeknik Kesehatan, I, pp. 190-
209.

Sawyer, S. M. et al. (2018) 'Viewpoint The age of adolescence', 4642(18), pp. 1-6.

Scheirer, M. A. and Dearing, J. W. (2011) 'An Agenda for Research on the Sustainability of Public Health Programs', 101(11), pp. 20592067.

Setianingsih, Y. A., Wahyati, E. and Widyorini, E. (2015) 'Pelaksanaan Kebijakan Kawasan Tanpa Rokok ( KTR ) Sebagai Bagian Dari Perilaku Hidup Bersih Dan Sehat ( PHBS ) Di Lingkungan Pendidikan', Jurnal Hukum Kesehatan Soepra, 1, Nomor 1, pp. 6-14.

Silele, E. et al. (2017) 'Evaluasi Pengelolaan Dana Bantuan Operasional Sekolah', 5(2), pp. 1626-1635.

So, L. et al. (2019) 'Implementation fi delity and adolescent smoking : The $X$ : IT study - A school randomized smoking prevention trial', 72(January 2018), pp. 2432.

Sutha, D. W. (2016) 'Analisis Lingkungan Sosial terhadap Perilaku Merokok Remaja Di Kecamatan Pangarengan Kabupaten Sampang Madura', Jurmal Manajemen Kesehatan STIKES Yayasan RS. Dr. Soetomo, 2(1), pp. 43-59.

Thomson, G. et al. (2013) 'Health \& Place Informing outdoor smokefree policy: Methods for measuring the proportion of people smoking in outdoor public areas', Health \& Place. Elsevier, 20, pp. 19-24.

Thurston, A. et al. (2019) 'A randomized controlled e ffi cacy trial of a smoking prevention programme with Grade 8 students in high schools', International Journal of Educational Research. Elsevier, 93(July 2018), pp. 23-32.

Trinidad, D. R., Gilpin, E. A. and Pierce, J. P. (2005) 'Compliance and support for smoke-free school policies', 20(4), pp. 466-475.

Ulfah, N. H., Katmawanti, S. and Tama, T. D. (2015) 'Design Kawasan Tanpa Rokok ( KTR ) Fakultas Ilmu Keolahragaan Universitas Negeri Malang', Jurnal Universitas Negeri Malang, 2, pp. 1-11.

Urbán, R. (2010) 'Early smoking experience in adolescents', 
Addictive Behaviors. Elsevier Ltd, 35(6), pp. 612-615.

Waliyanti, E. and Sandika, Y. H. (2017) 'Faktor - Faktor yang mempengaruhi Pelaksanaan Kebijakan Kamus Bebas Asap Rokok Di Universitas Muhammadiyah Yogjakarta', Jurnal Kesehatan Masyarakat, I, pp. 135-142.

WHO (2015) Global Youth Tobacco Survey (GYTS): Indonesia report 2014, Who-Searo.

Widiastini, L. P. (2010) 'Penyuluhan Meningkatkan Pengetahuan, Sikap Dan Perilaku Tentang Pemeriksaan
Payudara Sendiri dalam Upaya Deteksi Awal Kanker Payudara Pada Siswo Di SMAN mengwi Badung', Kebidanan Politeknik Kesehatan, 5, pp. 76-81.

Wiium, N., Burgess, S. and Moore, L. (2011) 'Brief report: Multilevel analysis of school smoking policy and pupil smoking behaviour in Wales', Journal of Adolescence. Elsevier Ltd, 34(2), pp. 385-389.

Willian T.O 'Donohue, Lorraine T.Benuto, L. W. T. (2013) Handbook of Adolescent Health Psychology. Reno, New York, USA: Springer. doi: $10.1007 / 978-1-4614-6633-8$. 